\title{
Role of citizen science in GIS mapping of Indian grey hornbill in Uttar Pradesh
}

\begin{abstract}
Hornbills are noticeable and familiar birds through nine species occurring in India. Indian Grey Hornbill is a fairly common, mostly arboreal found throughout India. Out of nine species Indian grey hornbill have been studied extensively in some parts of India. Indian grey hornbill (Ocyceros birostris) prefers dry deciduous forests, but these habitats are subjected to maximum anthropogenic disturbances. Due to rapidly changing habitations a gap has been created about their distribution, status, population size, and adaptations Most Conservation efforts done within protected area but apart from protected areas citizen science is an online platform play a crucial role in conservation and population status precisely to record communal sightings of Indian grey hornbill from anywhere in India? The purpose of the study is to boost birders, nature aficionados, and wildlife photographers to share more and more information on hornbill status, presence, behaviour, and conservational measures. The foremost objective is to encourage citizen participation in generate baseline information using sight records and enable long-term monitoring of Indian grey hornbill in Uttar Pradesh. The present study deals with the distribution of Indian grey hornbill in Uttar Pradesh and the data used is taken from the citizen science database of eBird.

The complete dataset of Indian grey hornbill from the 2008-2017 was used to prepare the distribution maps in different years. From 2008 to 2017 had received 966 records from 1,210 contributors across 43 districts of Uttar Pradesh. Mean number of most sighted reported districts were Lucknow (18.7), Agra (14.6), Gautam Budh Nagar (7.4), Kanpur Nagar (6.9), Bareilly (5.9) and Allahabad (5). The species was reported both protected as well as unprotected area. The citizen science data obtained thus has the potential for increasing our understanding of current hornbill distribution patterns, and for categorizing important sites for conservation/protection. This data can also be used to study the population trends and even to perform occupancy modeling and habitat modeling of hornbill species in Uttar Pradesh.
\end{abstract}

Keywords: eBird, hornbill, sighting pattern, citizen science, GIS mapping

\section{Introduction}

The Indian grey hornbill is found mainly on the plains up to approximately 2000 feet ranging from the foothills of the Himalayas southwards restricted on the west by the Indus system and the Gangetic delta on the east. Hornbills are secondary cavity nesters, consuming usual cavities or those excavated by other birds. ${ }^{1}$ Hornbills often display high nest-site loyalty, returning to the same nest cavity year after year. ${ }^{2}$ The breeding behaviors of hornbills are distinctive in that the female seals herself into a nest cavity and leaves only a narrow slit through which the male passes her food until the nesting period is finished. Though, this slow breeding birds is tremendously vulnerable to threats from anthropogenic pressures like hunting and deforestation. ${ }^{3}$

In India it is distributed throughout the country and earlier study on hornbills has been conducted on many edges of their biology such as breeding, nest site selection, foraging and diet. ${ }^{4-15}$ But there was very scant data is available on distribution, status and abundance patterns of hornbills, mainly in the case of large scale landscape transformations and unending fragmentation and disturbance. ${ }^{16-18}$ According to a recent survey by Balasubramanian et al., ${ }^{19,20}$ recorded hornbill distribution in a number of sites in Kerala, Tamil Nadu, Karnataka, and Goa in the Western Ghats, as well as in parts of the Eastern Ghats.

Indian grey hornbill (Ocyceros birostris) prefers dry deciduous forests, but these habitats are subjected to maximum anthropogenic
Volume 3 Issue 3 - 2019

\author{
Adesh Kumar, ${ }^{1,2}$ Ankit Sinha, ' Amita \\ Kanaujia ${ }^{1,2}$ \\ 'Department of Zoology, University of Lucknow, India \\ ${ }^{2}$ Institute for Wildlife Sciences, University of Lucknow, India
}

Correspondence: Adesh Kumar, Biodiversity \& Wildlife Conservation Lab, Department of Zoology, University of Lucknow, Lucknow-226007, Uttar Pradesh, India, Email adesh.science@gmail.com

Received: February 05, 2019 | Published: April 25, 2019 disturbances. Due to rapidly changing habitations a gap has been created about their distribution, status, population size, and adaptations. Most Conservation efforts done within protected area but apart from protected areas citizen science is an online platform play a crucial role in conservation and population status precisely to record communal sightings of Indian grey hornbill from anywhere in India? An assessment of the distribution of Turdoides striata (Dumont, 1823) (Aves: Passeriformes: Leiothrichidae) in India was performed by online investigation during 2014-2015 (targeting 232 ornithological forums comprising of over 4,00,000 members) to obtain information on the species' location, and number of individuals in each social group in India. The result revealed that a total of 3,030 individual birds were recorded from 24 states and union territories of India. The study utilized public participation or citizen science data for the species, which has an apparently large distribution range. ${ }^{21}$

Routinely most of citizen science projects are big data collector, time-bound and short-term, and/or focused on a single question to solve a specific problem..$^{22}$ These initiatives also very much helpful in large-scale data collection of basic biological or ecological parameters that do not require significant training or specialization. Nevertheless, data therefore collected often provide understandings on largescale phenological patterns, and bird migration, impact of climate change. ${ }^{21-25}$ Citizen science agendas were principally measured as educational tools and helpful to collect large data. ${ }^{26-28}$ Due to lacking in manpower and funding, a large scale data could not gather, so solving this problem cadre of citizen scientists paly a significance role 
to obtain the data for lager ecological projects..$^{29-31}$ eBird is a large citizen science database that holds a large and increasing capacity of bird count data. ${ }^{32-35}$ The purpose of the study is to boost birders, nature aficionados, and wildlife photographers to share more and more information on hornbill status, presence, behaviour, and conservational measures. The foremost objective is to encourage citizen participation in generate baseline information using sight records and enable longterm monitoring of Indian grey hornbill in Uttar Pradesh.

\section{Study area}

Uttar Pradesh is confined on the Shivalik Range which forms the southern foothills of the Himalayas, slopes down in to a boulder bed called Bhabhar, the transitional belt running along the entire length of the state is called the Terai and bhabhar area. The present study deals with the distribution of Indian grey hornbill in Uttar Pradesh and the data used is taken from the citizen science database of eBird. The study was conducted from 2008 to 2017 across the entire state of Uttar Pradesh. This state lies between $23^{\circ} 52^{\prime}-30^{\circ} 24^{\prime} \mathrm{N}$ latitude and $77^{\circ} 5^{\prime}$ $84^{\circ} 38^{\prime}$ E longitude covering over $294,410 \mathrm{~km}^{2}$. Average rainfall varies between $600 \mathrm{~mm}$ and $2,500 \mathrm{~mm}$, most of which comes during monsoon period of rainy season. The climate of the state is tropical monsoon. The average temperature varies in the plains from 3 to $4{ }^{\circ} \mathrm{C}$ in January to 43 to $45^{\circ} \mathrm{C}$ in May and June. There are three distinct seasons-winter from October to February, summer from March to mid-June, and the rainy season from June to September. The study includes the whole of Uttar Pradesh which divided in to four different zones namely central (zone 1) east (zone 2), west (zone 3), and Bundelkhand zone U.P. (zone 4). The study includes the whole of Uttar Pradesh which will be divided in to forests cover, agricultural area, non-agricultural area protected areas, non-protected areas, Forests, Urban and human habitations (Figure 1).

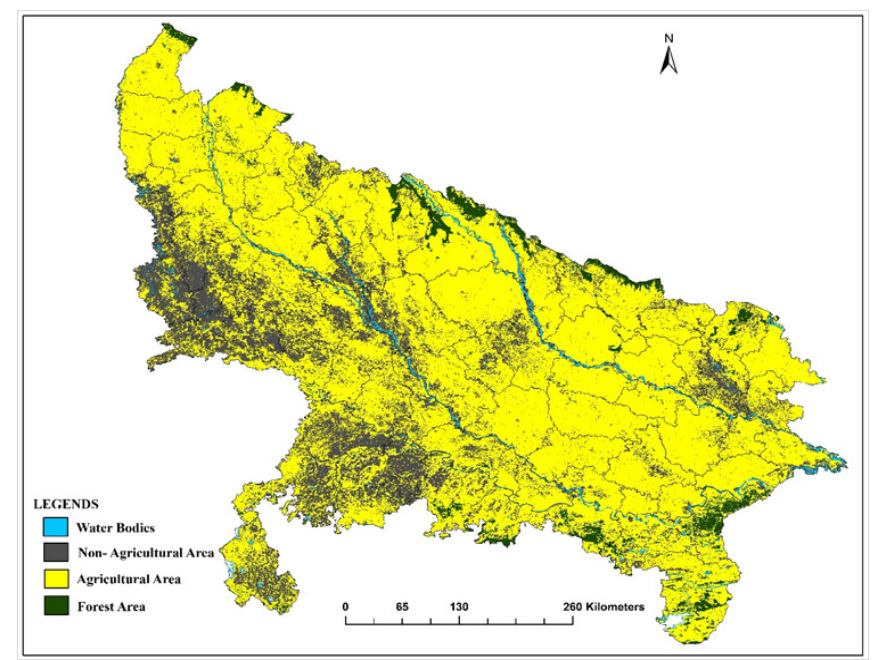

Figure I Map of Study area (Uttar Pradesh) with land use pattern

\section{Material and methods}

Mapping is done using ArcGIS software and resulted in various patterns of hornbills' sightings in the state. Maps are prepared showing spotting patterns of hornbill and the comparison of sights in different years.

\section{Data collection}

We have taken the permission request to access the data and after permission, downloaded the complete eBird basic dataset and again reduced it to checklists from the 2008 to 2017. The data can be downloaded as a comma-separated values (CSV) file, or as an Excel file. Annual summary of data has sorted for each year of whole Uttar Pradesh. We eliminated the incomplete checklists or data and repetitions of spot sighting and shortening the repetitive data sets. Once estimating population trends for the species, only used checklists from eBird locations, as defined by the "locality ID" and GPS locations, with at least one record for the species. The citizen scientists observed the different numbers of a species at a particular sites and GPS, we determined maximum number count of the species at that particular locations and others were eliminated. The most prominent observing sites Some of the reported sites were visited for verification during 2008-2017.The survey involved of questions concerning to- the species' location, group size, (i.e., total number of birds present in each sighted group), and current conservation concerns. We also analyzed population changes for distribution of species that occur on study area and awareness and concern of local birders, students and public related to species conservation.

\section{Statistical Analysis}

Mapping is done using Arc GIS 10.5 software and resulted in various patterns of Indian grey hornbill sightings in the state. Maps are prepared showing sighting and distribution patterns of Indian grey hornbill and the comparison of sights in different years. Other statistical data managed by IBM SPSS software version 20 .

\section{Results and discussion}

The complete dataset of Indian grey hornbill from the 2008-2017 was used to prepare the distribution maps in different years. From 2008 to 2017 had received 966 records from 1,210 contributors across 43 districts of Uttar Pradesh (Table 1). Mean number of most sighted reported districts were Lucknow (18.7), Agra (14.6), Gautam Budh Nagar (7.4), Kanpur Nagar (6.9), Bareilly (5.9) and Allahabad (5). The species was reported both protected as well as unprotected area (Table 2). More or less the hornbills were reported either as single birds, or in pair or large flocks of less than 10. GIS Mapping of Indian grey hornbill shows that distribution and occurrence of species is positive correlated with the non-agricultural area i.e. Educational and Research Institute, Parks, monuments as well as green cover of state Uttar Pradesh respectively, means the region where the greener cover area (parks, reserve forests, monuments), more chance of spotting or reporting the bird (Figure 2-11).

The Indian Grey Hornbill was reported and harboring its populations in urban areas and green spaces gardens, parks, and forest patches within cities like Delhi, Mumbai, Pune, Bangalore, Lucknow, and Kanpur. ${ }^{36}$ The Indian Grey Hornbill is widespread in Uttar Pradesh, and occupies a diverse array of habitats from urban landscapes to forests, protected as well as unprotected areas. Indian grey hornbill species was reported from 43 of the 75 districts of the Uttar Pradesh states. This is an indication of the wide terrestrial reporting of hornbills from across the state. In India it is distributed throughout the country as well as reported to occur in the dry deciduous tracts of the Eastern Ghats and foothill forests of the Western Ghats, ${ }^{3}$ excepting for Malabar, parts of Rajasthan and Assam. ${ }^{37}$ More than 50\% of the reports of grey hornbill species were from Agra, Allahabad, Behraich, Bareilly, Gautambudh Nagar, Gonda, J.P. Nagar, Kanpur Nagar, Kheri, Lucknow districts. Thus the results show that citizen from these districts are more aware and have feel the responsibilities towards the biodiversity conservation. However, others districts also have the reporting of species but this is in small in count. It was 
encouraging to see hornbill reports from districts like Gorakhpur, Mirzapur, Maharajganj, Rampur, Mainpuri and Sonbhadra, as there is scarcity of literature on the presence of hornbills there indicates that citizens of these districts also taking interest in bird watching and its vibrant sign for the little step of conservation from small towns and cities. Breeding was also reported for Indian grey hornbill only from came equally from within, and from outside Protected Areas. Though citizen science is a great tool for data collection, but also have its limitations to how the data generated can be understood or used. There are very limited interpretations on hornbill distribution/ presence based on the records. We could not get information about sightings in some parts of the state for several reasons such as lack of awareness about bird watching, eBird, lack of interest/time. The areas where no reporting or records was found, doesn't mean that absence of birds in that area. In order to continue to provide broad citywide data on grey hornbill, the eBird has needed to extend as well, adding new routes and locations as required, it also requires further volunteers and citizen science workforces to establish the itineraries (Table 1 \& 2) (Figure 2-12). . $3,39^{3}$

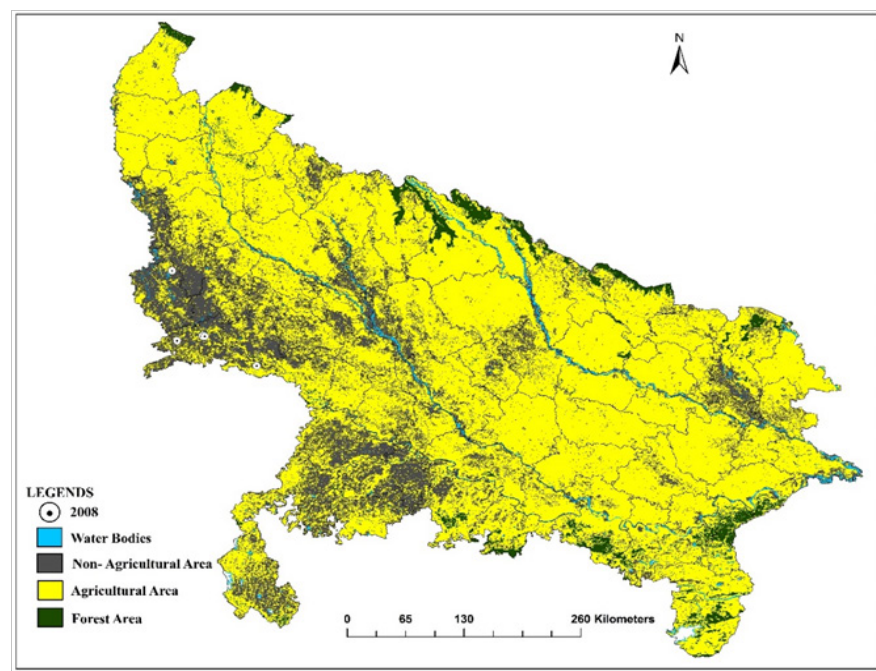

Figure 2 Population status and distribution of Indian grey hornbill in 2008.

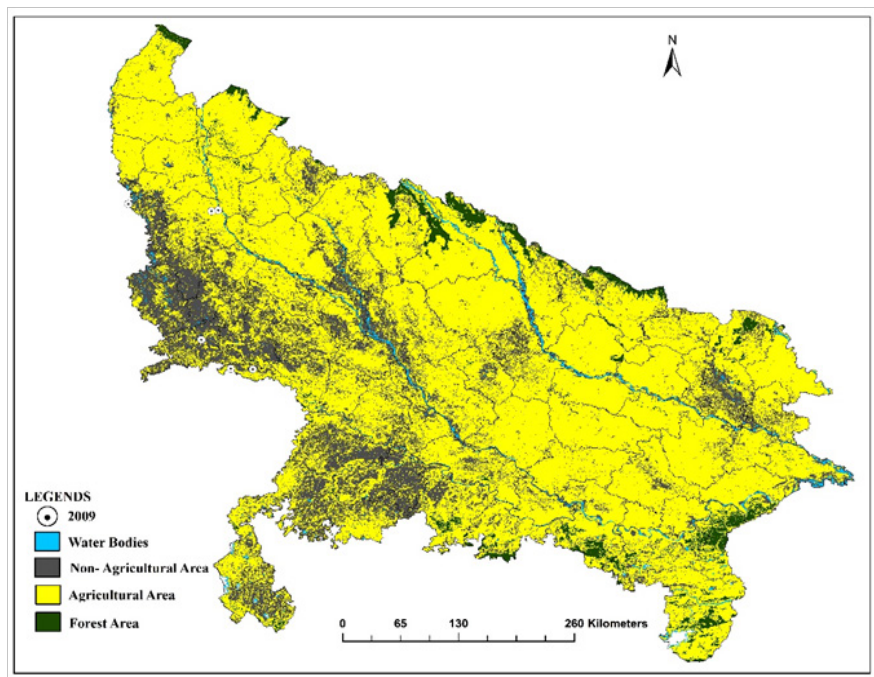

Figure 3 Population status and distribution of Indian grey hornbill in 2009.

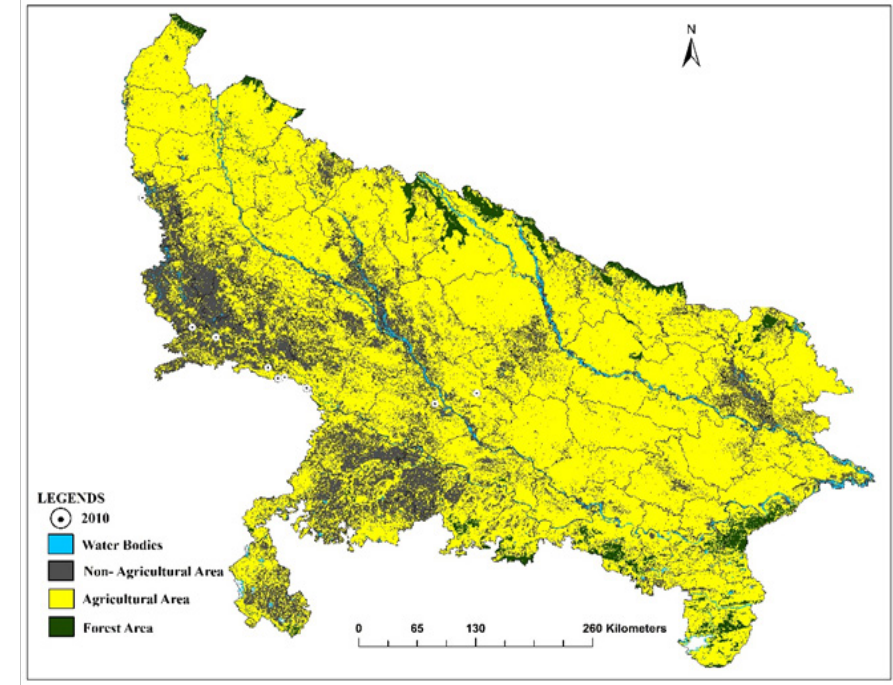

Figure 4 Population status and distribution of Indian grey hornbill in 2010.

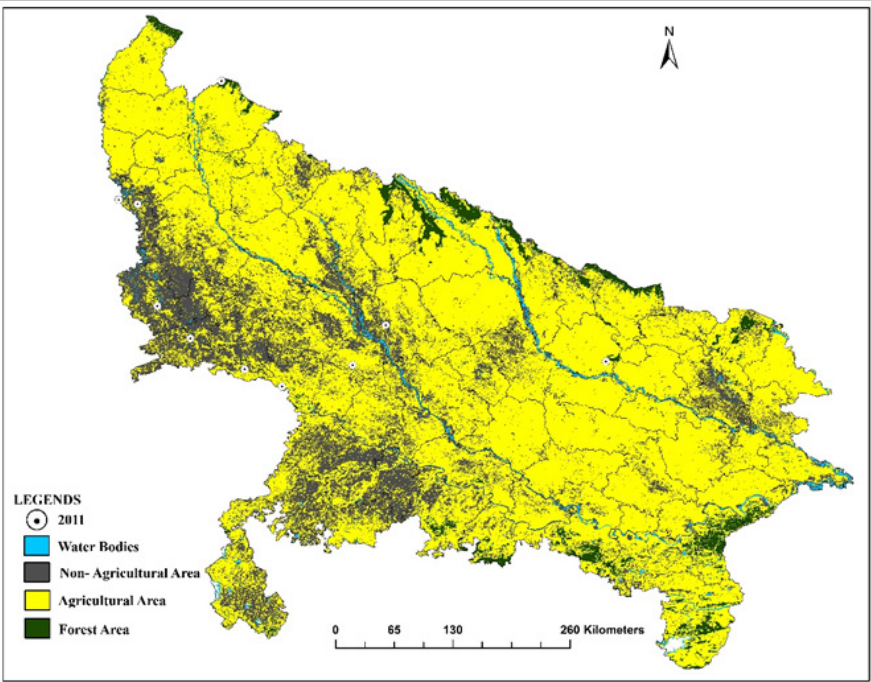

Figure 5 Population status and distribution of Indian grey hornbill in $201 \mathrm{I}$.

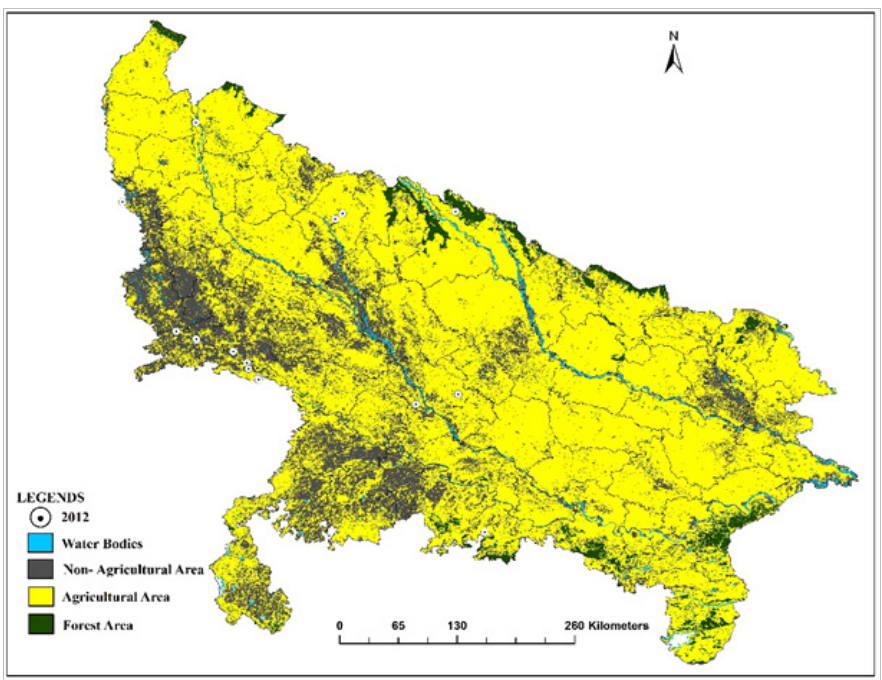

Figure 6 Population status and distribution of Indian grey hornbill in 2012 . 


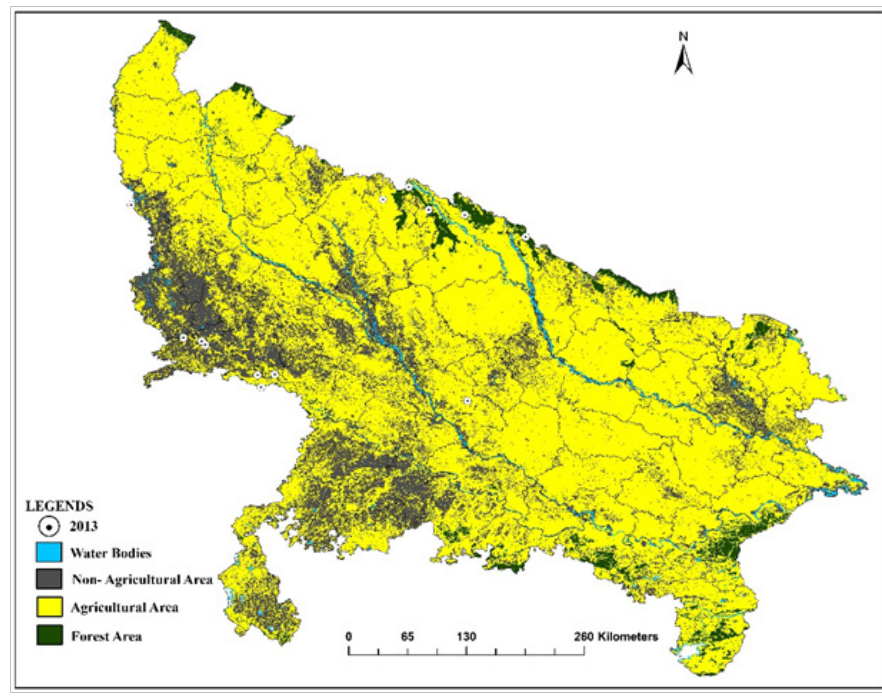

Figure 7 Population status and distribution of Indian grey hornbill in 2013.

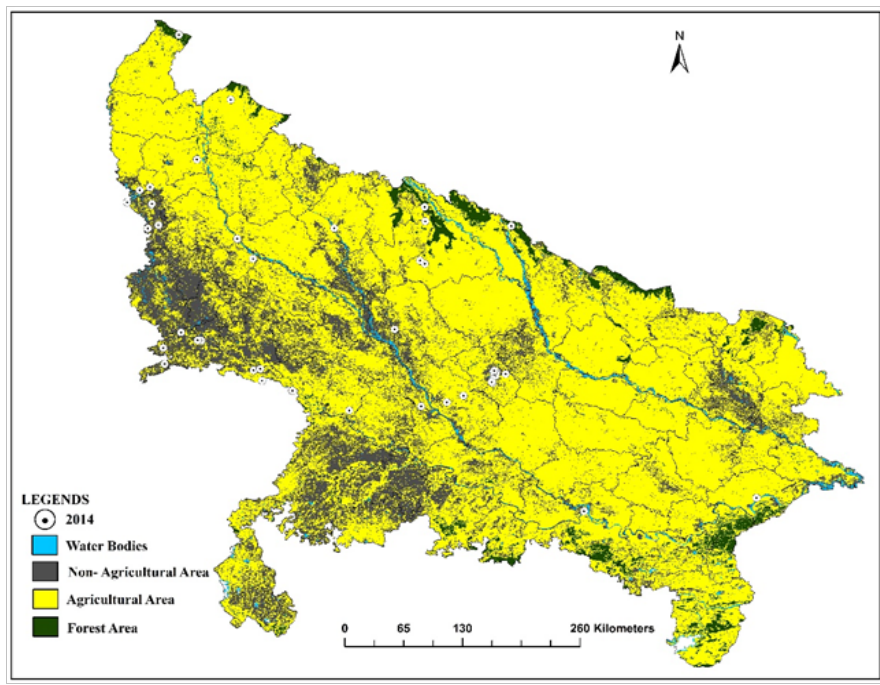

Figure 8 Population status and distribution of Indian grey hornbill in 2014.

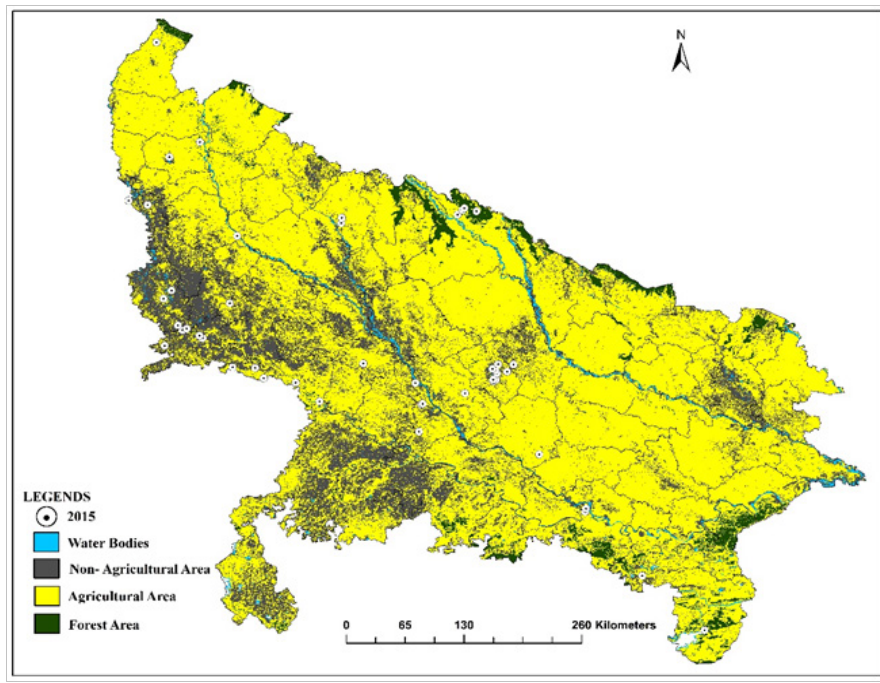

Figure 9 Population status and distribution of Indian grey hornbill in 2015.

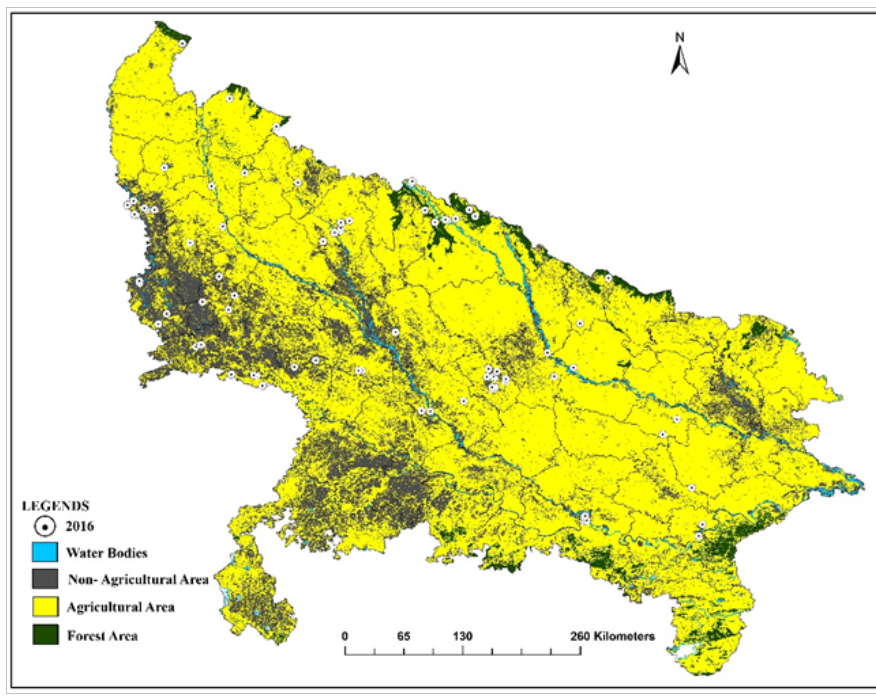

Figure 10 Population status and distribution of Indian grey hornbill in 2016.

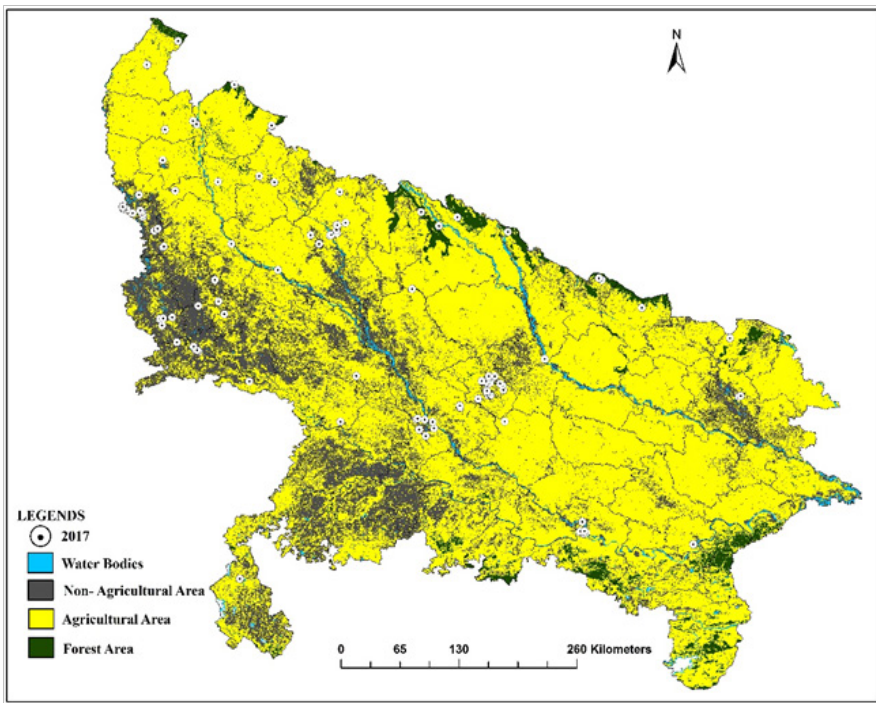

Figure II Population status and distribution of Indian grey hornbill in 2017.

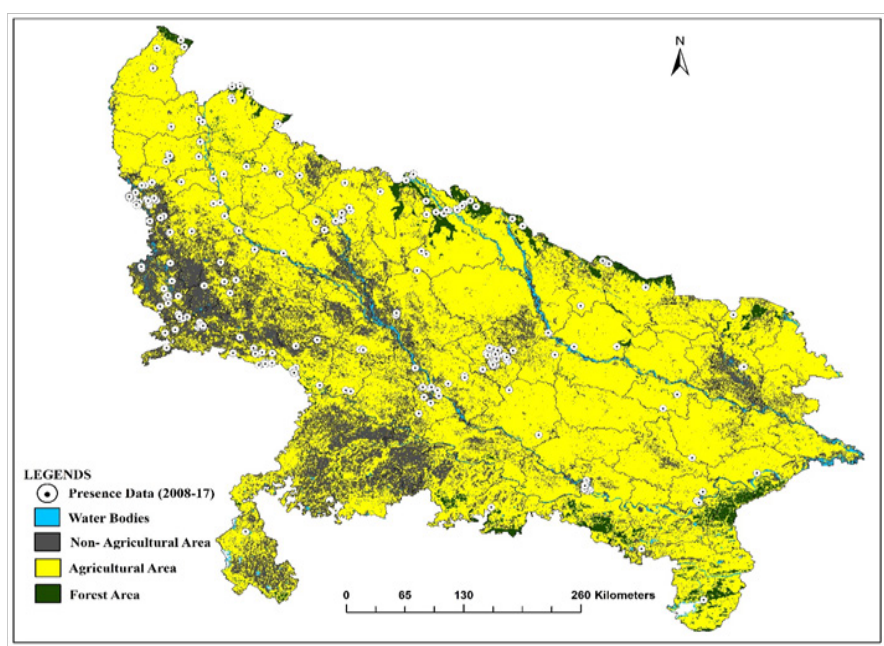

Figure 12 Overall scenario status and distribution of Indian grey hornbill in Uttar Pradesh (2008-2017). 
Table I Total number of individuals of Indian Grey Hornbill and social groups observed in the various Districts of Uttar Pradesh

\begin{tabular}{lllll}
\hline SN & Year & $\begin{array}{l}\text { Total number } \\
\text { of group } \\
\text { observed }\end{array}$ & $\begin{array}{l}\text { Total number } \\
\text { of observer }\end{array}$ & $\begin{array}{l}\text { Total number } \\
\text { of individuals } \\
\text { observed }\end{array}$ \\
\hline 1 & 2008 & 6 & 41 & 4 \\
2 & 2009 & 8 & 22 & 9 \\
3 & 2010 & 11 & 16 & 22 \\
4 & 2011 & 12 & 14 & 59 \\
5 & 2012 & 17 & 74 & 26 \\
6 & 2013 & 11 & 61 & 11 \\
7 & 2014 & 20 & 91 & 53 \\
8 & 2015 & 50 & 158 & 163 \\
9 & 2016 & 96 & 426 & 289 \\
10 & 2017 & 117 & 307 & 330 \\
\hline
\end{tabular}

Table 2 Mean number of individuals of Indian Grey Hornbill observed in the various Districts of Uttar Pradesh

\begin{tabular}{|c|c|c|c|}
\hline SN & County/Area & $\begin{array}{l}\text { Mean number of } \\
\text { Individual } / \pm \mathrm{SD}_{\mathrm{x}}\end{array}$ & Variance $\sigma^{2}$ \\
\hline I. & Agra & $14.6 \pm 4.26$ & 163.44 \\
\hline 2. & Aligarh & $1.5 \pm 0.34$ & 1.05 \\
\hline 3. & Allahabad & $5 \pm 0.97$ & 9.55 \\
\hline 4. & Ambedkar Nagar & $0.3 \pm 0.15$ & 0.21 \\
\hline 5. & Behraich & $3.4 \pm 1.42$ & 18.24 \\
\hline 6. & Barabanki & $0.2 \pm 0.13$ & 0.16 \\
\hline 7. & Bareilly & $5.9 \pm 0.95$ & 8.29 \\
\hline 8. & Bijnor & $0.8 \pm 0.53$ & 2.56 \\
\hline 9. & Bulandshahar & $2.4 \pm 0.6$ & 3.24 \\
\hline 10. & Etah & $\mathrm{I} .5 \pm 0.26$ & 0.65 \\
\hline 11. & Etawah & $0.4 \pm 0.26$ & 0.64 \\
\hline 12. & $\begin{array}{l}\text { Gautambudh } \\
\text { Nagar }\end{array}$ & $7.4 \pm 3.14$ & 89.24 \\
\hline 13. & Gonda & $3.8 \pm 3.01$ & 81.66 \\
\hline 14. & Hardoi & $1.8 \pm 1.09$ & 10.76 \\
\hline 15. & Jaunpur & $0.3 \pm 0.3$ & 0.81 \\
\hline 16. & JP Nagar & $0.4 \pm 0.30$ & 0.84 \\
\hline 17. & Kannauj & $2.2 \pm 1.55$ & 21.76 \\
\hline 18. & Kanpur Nagar & $6.9 \pm 3.41$ & 104.69 \\
\hline 19. & Kheri & $4.1 \pm 1.37$ & 17.09 \\
\hline 20. & Lucknow & $18.7 \pm 7.52$ & $509.4 I$ \\
\hline 21. & Mahamayanagar & $1.8 \pm 1.20$ & 13.16 \\
\hline 22. & Auraiya & $0.5 \pm 0.34$ & 1.05 \\
\hline 23. & Mainpuri & $0.2 \pm 0.2$ & 0.36 \\
\hline 24. & Mathura & $2.7 \pm 1.55$ & 21.81 \\
\hline 25. & Meerut & $1.4 \pm 0.66$ & 4.04 \\
\hline 26. & Pilibhit & $1.5 \pm 0.74$ & 5.05 \\
\hline
\end{tabular}

\begin{tabular}{llll}
\multicolumn{2}{c}{ Table Continued } & \\
\hline SN & County/Area & $\begin{array}{l}\text { Mean number of } \\
\text { Individual/ } \pm \text { SD }_{x-}\end{array}$ & Variance $\boldsymbol{\sigma}^{2}$ \\
\hline 27. & Rampur & $0.2 \pm 0.2$ & 0.36 \\
28. & Saharanpur & $1.1 \pm 0.64$ & 3.69 \\
29. & Shrawasti & $1.1 \pm 0.64$ & 3.69 \\
30. & Unnao & $2 \pm 0.86$ & 6.8 \\
31. & Varanasi & $0.7 \pm 0.36$ & 1.21 \\
32. & Shahjhanpur & $0.7 \pm 0.51$ & 2.41 \\
33. & Mirzapur & $0.1 \pm 0.1$ & 0.09 \\
34. & Sonbhadra & $0.2 \pm 0.2$ & 0.36 \\
35. & Lalitpur & $0.4 \pm 0.26$ & 0.64 \\
36. & Rai-bareily & $0.2 \pm 0.2$ & 0.36 \\
37. & Gorakhpur & $0.1 \pm 0.1$ & 0.09 \\
38. & Maharajganj & $0.1 \pm 0.1$ & 0.09 \\
39. & Balrampur & $0.4 \pm 0.4$ & 1.44 \\
40. & Badayun & $0.2 \pm 0.2$ & 0.36 \\
41. & Gaziabad & $1 \pm 0.69$ & 4.4 \\
42. & Moradabad & $0.4 \pm 0.4$ & 1.44 \\
43. & Mujjafarnagar & $0.8 \pm 0.8$ & 5.76 \\
\hline
\end{tabular}

\section{Conclusion}

The citizen science data obtained thus has the potential for increasing our understanding of current hornbill distribution patterns, and for categorizing important sites for conservation/protection. Results from these studies by citizen scientists can be invaluable in identifying key areas of ecological significance within a city and track the pattern of land use. This data can also be used to study the population trends and even to perform occupancy modeling, identify the species "abundance hotspots" and habitat modeling of hornbill species in Uttar Pradesh.

\section{Acknowledgments}

The authors thank the Head, Department of Zoology, University of Lucknow and Director, ONGC Center for Advanced Studies for providing facility and administrative support. We are also thankful to the all the citizen scientists and ebirders of the Uttar Pradesh whosoever has given primary and secondary information about the status and occurrence. Special thanks to eBird for provide the data of Indian Grey Hornbill.

\section{Conflicts of interest}

The authors declare that there is no conflict of interest.

\section{References}

1. Kemp AC. The Hornbills: Bucerotiformes. Oxford university press, Oxford, 1995;302.

2. Gupta N, Talukdar G. A Babbler's tale: assessing the distribution of Turdoides striata (Dumont, 1823) (Aves: Passeriformes: Leiothrichidae) in India. Journal of Threatened Taxa. 2018;10(3):11450-11453.

3. Kummer JA, Bayne EM, Machtans CS. Use of citizen science to identify factors affecting bird-window collision risk at houses. The Condor. 2016;118(3):624-639. 
4. Brewer C. Outreach and partnership programs for conservation education where endangered species conservation and research occur. Conservation Biology. 2002;16(1):4-6

5. Datta A, Rawat GS. Nest-site selection and nesting success of three hornbill species in Arunachal Pradesh, north-east India: Buceros bicornis, Aceros undulatus, and Anthracoceros albirostris. Bird Conservation International. 2004;14(1):39-52.

6. Datta A. An ecological study of sympatric hornbills and fruiting patterns in a tropical forest in Arunachal Pradesh. PhD thesis. Saurashtra University. 2001.

7. Datta A. Hornbill abundance in unlogged forest, selectively logged fores and a plantation in western Arunachal Pradesh. Oryx. 1998;32(4):285294.

8. Kannan R. Ecology and conservation of the Great Pied Hornbill (Buceros bicornis) in the Western Ghats of southern India. PhD dissertation. Fayetteville: University of Arkansas. 1994.

9. Kinnaird MF, O Brien TG. The ecology \& conservation of Asian hornbills. Farmers of the forest. 1st Edn. Chicago \& London: The University of Chicago Press. 2007.

10. Mudappa D. Breeding biology of the Malabar Grey Hornbill (Ocyceros griseus) in southern Western Ghats, India. J Bombay Nat Hist Soc. 2000;97(1):15-24.

11. Mudappa D. Eight years monitoring of Malabar Grey Hornbill Ocyceros griseus nest cavity use and dynamics in the Anamalai rainforest, India In: Lum S, Poonswad P, Editors. The ecology of hornbills: reproduction and population. Bangkok: Pimdee Karnpim Co. Ltd. 2005.

12. O Brien TG, Kinnaird MF, Jepson P, et al. Effect of forest size and structure on the distribution of Sumba Wreathed Hornbill Aceros everetti. In: Poonswad P, Editor. The Asian hornbills: ecology and conservation. Bangkok: Thai Studies in Biodiversity No. 2. 1998.

13. Reddy MS, Muralidhar KS, Gandhi M, et al. Distribution and variation in number of Malabar Pied Hornbills Anthracoceros coronatus (Boddaert) in selected areas of north Kanara forest of Western Ghats in Karnataka, India. The Indian Zoologist. 1990;14:63-73.

14. Ebersole R. Adventures afield: volunteers tune in to frog talk. National Wildlife. 2003;41:18-19.

15. Pattengill Semmens CV, Semmens BX. Conservation and managemen applications of the reef volunteer fish monitoring program. Environ Monit Assess. 2003;81(1-3):43-50.

16. Reddy MS. Some aspects of ecology and behaviour of hornbills with special reference to Anthracoceros coronatus (Boddaert) from North Kanara district of Western Ghats. PhD thesis. Karnataka University. 1988.

17. Clark CJ. eBird records show substantial growth of the Allen's Hummingbird (Selasphorus sasin sedentarius) population in urban Southern California. The Condor. 2017;119(1):122-130.

18. La Sorte FA, Tingley MW, Hurlbert AH. The role of urban and agricultural areas during avian migration: an assessment of within-year temporal turnover. Glob Ecol Biogeography. 2014;23(11):1225-1234.

19. Balasubramanian P, Ravi R, Venkitachalam R, et al. Status and conservation of the hornbills in Southern India. In: Kemp AC, Kemp MI. Editors. The active management of hornbills and their habitat for conservation. CDROM. Proceedings of the 4th International Hornbill conference. 2007.
20. Balasubramanian P, Vijayan VS, Prasad N, et al. Status and distribution of hornbills in the Western Ghats. Unpublished report. Coimbatore: Salim Ali Centre for Ornithology and Natural History. 2004.

21. Mendiratta U, Quader S. Migrant Watch: changes and results from the second year. Indian Birds. 2009;4(4):122-126.

22. Mudappa D, Kannan R. Nest-site characteristics and nesting success of the Malabar Gray Hornbill in the southern Western Ghats, India. Wilson Bulletin. 1997;109(1):102-111.

23. Quader S, Raza RH. Migrant Watch: A citizen science programme for the study of bird migration. Indian BIRDS. 2008;3(6):202-209.

24. Raman TRS, Mudappa D. Correlates of hornbill distribution and abundance in rainforest fragments in the southern Western Ghats, India. Bird Conservation International. 2003;13(3):199-212.

25. Brossard D, Lewenstein B, Bonney R. Scientific knowledge and attitude change: the impact of a citizen science project. International Journal of Science Education. 2005;27(9):1099-1121.

26. Callaghan CT, Gawlik DE. Efficacy of eBird data as an aid in conservation planning and monitoring. J F Ornithol. 2015;86(4):298-304.

27. Fink D, Hochachka WM, Zuckerberg B, et al. Spatiotemporal exploratory models for broadscale survey data. Ecol Appl. 2010;20(8):2131-2147.

28. Evans C, Abrams E, Reitsma R, et al. The Neighborhood Nestwatch Program: participant outcomes of a citizen-science ecological research project. Conservation Biology. 2005;19(3):589-594.

29. Kannan R, James DA. Breeding biology of the Great Pied Hornbill (Buceros bicornis) in the Anaimalai Hills of Southern India. J Bombay Nat Hist Soc. 1997;94(3):451-465.

30. Quader S Mendiratta. Nature in a changing climate. 2010;68-70.

31. Fore LS, Paulsen K, O Laughlin K. Assessing the performance of volunteers in monitoring streams. Journal of Freshwater Biology. 2001;46(1):109-123.

32. Mayor SJ, Guralnick RP, Tingley MW, et al. Increasing phenological asynchrony between spring green-up and arrival of migratory birds. Scientific Reports.2017;7:1902.

33. Supp SR, La Sorte FA, Cormier TA, et al. Citizen-science data provides new insight into annual and seasonal variation in migration patterns. Ecosphere. 2015;6(1):1-19.

34. Walker J, Taylor PD. Using eBird data to model population change of migratory bird species. Avian Conserv Ecol. 2017;12:(1):4.

35. Kemp AC. A review of the hornbill's biology and radiation. Living Bird. 1979; 17:105-136.

36. Datta A, Rawat GS. Foraging patterns of sympatric hornbills during the nonbreeding season in Arunachal Pradesh, northeast India. Biotropica. 2003;35(2):208-218.

37. Ali S, JC Daniel. The book of Indian birds. 13th Edn. Oxford university press, New Delhi. 2002.

38. Sullivan BL, Wood CL, Iliff RE, et al. eBird: a citizen-based bird observation network in the biological sciences. Biol Conserv. 2009; 142(10):2282-2292.

39. Datta A, Naniwadekar R, Rao M, et al. Hornbill Watch: A citizen science initiative for Indian hornbills. Indian BIRDS. 2018;14(3):65-70. 